\title{
21. Yüzyılın Sosyal Güvenlik Sorunu Olarak Evsizler: 'Evsizler'i Konu Alan Reklam Kampanyaları Üzerine Göstergebilimsel Bir İnceleme
}

\author{
Mustafa KARACA ${ }^{1}$ \\ Mehmet Ali GAZiं ${ }^{23}$ \\ Caner ÇAKI ${ }^{4}$
}

\begin{abstract}
Öz
Evsizleri konu alan bu çalışmada, reklam kampanyalarında bu sorunun nasıl yansıtıldığının ve sorunla ilgili ne gibi çözüm önerilerinin sunulduğunun irdelenmesi amaçlanmıştır. Bu amaç kapsamında nitel betimleyici bir yaklaşıma sahip olan çalışmada, evsizlerin yoğun olarak yaşadığı 9 ülkenin yanı sıra Türkiye`nin de içinde bulunduğu on farklı ülkede evsizlerin sorunlarına yönelik hazırlanan reklam kampanyaları göstergebilimsel analiz yöntemi ile incelenmiştir. Çalışma, evsizleri konu alan reklam kampanyalarında verilen mesajları açıklaması bakımından önem taşımaktadır. İncelenen reklam kampanyalarında hüzün duygusu üzerinden kitlelere hitap edildiği ve kitlelerin evsizler ile empati kurmalarının amaçlandığı tespit edilmiştir. Bu doğrultuda, kitlelerin evsizlere yönelik daha duyarlı olmasının ve evsizler için düzenlenen yardım kampanyalarına destek vermesinin hedeflendiği sonucuna ulaşılmıştır.
\end{abstract}

Anahtar Kelimeler: Sosyal güvenlik, evsizler, reklam kampanyaları, göstergebilim

ATIF: Karaca, M., Gazi, M. A. \& Çakı, C. (2019). 21. Yüzyııın Sosyal Güvenlik Sorunu Olarak Evsizler: 'Evsizler’i Konu Alan Reklam Kampanyaları Üzerine Göstergebilimsel Bir İnceleme. Akdeniz Üniversitesi İletișim Fakültesi Dergisi, 32, s. 505-527

1 Doç. Dr., Anadolu Üniversitesi, iktisadi ve İdari Bilimler Fakültesi, mustafa_karaca@anadolu.edu.tr, ORCID Numarası: 0000-0002-8204-6154..

2 Arş. Gör. Dr., Trabzon Üniversitesi, İletişim Fakültesi, mehmetaligazi@hotmail.com, ORCID Numarası: 0000-0002-9239-4187.

3 Sorumlu Yazar / Corresponding Author

4 Araş. Gör., İnönü Üniversitesi, İletişim Fakültesi, caner.caki@inonu.edu.tr, ORCID Numarası: 0000-0002-1523-4649. 


\title{
The Social Security Problem As Homeless of The 21st Century: A Semiotical Examination on Advertising Campaigns Regarding 'Homeless'
}

\begin{abstract}
In this study, which is about the homeless people, it was aimed to examine how this problem was reflected in advertising campaigns and what solutions were offered about the problem. The advertising campaigns prepared for the problems of homeless were analyzed by semiotic analysis method in ten different countries in which Turkey is also as well as 9 countries where homeless live intensely in the study which has qualitative descriptive approach under this purpose. The study is important in terms of revealing the messages given in advertising campaigns about homeless. It was found out that the ad campaigns were addressed to the masses through a sense of sadness and that the masses empathize with the homeless was aimed. In this respect, it was concluded that that the masses were more sensitive to the homeless and support the aid campaigns organized for the homeless was aimed.
\end{abstract}

Keywords: Social security, homeless, advertising campaigns, semiotics

\section{Giriș}

Son yıllarda yapılan araştırmalar dünya genelinde evsizlerin sayısında ciddi bir artışın yaşandığını göstermektedir (Yale Global, 2019). Özellikle ülkelerindeki iç savaştan kaçan göçmenlerin bir kısmının bulundukları ülkelerde evsiz durumuna düşmesi, evsiz sayısının daha da artmasına yol açmaktadır. Evsizlerin sayısında yaşanan artış, hükümetler için çözülmesi gereken yeni sorunları da beraberinde getirmektedir. Dünyanın farklı coğrafyalarında hükümetler, sosyal güvenlik politikaları kapsamında evsizlerin yaşadıkları sorunları en aza indirebilmek için barınak, yiyecek, giyim ve sağlık gibi yardımlar yapmaktadır. Buna karşın yüksek maliyeti nedeniyle yapılan yardımlar sürekli hale gelememekte ve bu durum hükümetlerin sosyal güvenlik uygulamaları çerçevesinde evsizlerin problemlerini kalıcı olarak çözmesini engellemektedir. Bu nedenle hükümet ve hükümet dışı kuruluşlar, evsizlerin yaşadıkları sorunlara dikkat çekebilmek için çeşitli reklam kampanyaları hazırlamaktadırlar. Hazırlanan reklam kampanyalarında evsizlerin yaşadıkları sorunlara yönelik olarak farkındalık oluşturulmakta, bu sayede toplum genelinde evsizler için yardımların artıııması ve hükümetler tarafından evsizlere yönelik yürütülen sosyal güvenlik politikalarının kamuoyu tarafından desteklenmesi amaçlanmaktadır.

Evsizlerin yaşadıkları problemleri inceleyen literatürde önemli akademik çalısmaların olduğu görülmektedir. Bunlardan ulusal çalışmalar içerisinde; Zima vd. (1994), evsiz çocukların duygusal ve davranışsal sorunlarını; Türkcan ve Türkcan (1996), evsizlerin psikiyatrik durumlarını; Özdemir (2010), evsizliği oluşturan temel nedenleri; İlhan ve Ergün (2010), evsizlerin sağlık problemlerini; Akyıldız (2017), evsizlik sorunu üzerine yürütülen çalışmaları; Yeter (2018), sivil toplum kuruluşlarının evsizlere yönelik hizmetlerini incelemiştir. Uluslararası çalışmalarda ise; Alperstein vd. (1988) ve Susser vd. (1990), evsizlerin sağlık sorunlarını; Kurtz vd. (1991), evsiz gençler- 
in sorunlarını; Padgett ve Struening (1992), evsizlerin alkol, uyuşturucu ve zihinsel problemlerini; Vostanis (1998), evsiz çocukların ve ailelerin ruh sağlığı sorunlarını; Galaif vd. (1999), evsiz kadınların uyuşturucu sorunlarını; Whitbeck vd. (2000), madde bağımlıı̆̆ı açısından evsizleri; Reinking vd. (2001), evsizlerin bağımlılık problemlerini; Rodell vd. (2001), evsiz gazilerin alkol sorunlarını; Anooshian (2005), evsiz çocukların hayatlarında şiddet ve saldırganlığı; Gaetz (2004), toplumdan dışlanma boyutunda evsiz gençleri; Benda (2005), evsizler arasında yaşanan travmayı; Lee ve Schreck (2005), evsiz insanların sokaklarda yaşadığı tehlikeleri; Harding ve Hamilton (2008), istismara uğrayan evsiz kadınları; Chiu (2009), evsiz göçmenlerin sağlık problemlerini; Breton ve Bunston (2009)evsiz kadınların hayatlarında fiziksel ve cinsel şiddeti; Jasinski (2010), evsiz kadınların hayatlarındaki şiddeti; Cheng ve Yang (2010), Tayvan özelinde evsizlerin problemlerini; Burke (2013), bölgesel işsizliğin evsizlerin demografik özellikleri, ihtiyaçları ve sağlık hizmetleri üzerindeki etkisini; Matheson (2014), evsizlerin kumar oynama sorunlarını; Bassuk ve Beardslee (2014), evsiz annelerin yaşadığı depresyonu; Hanratty (2017) işsizlik ve yoksulluğun evsiz oranları üzerindeki etkisini; Moore (2018), evsiz gençlerin okul boyutunda yaşadığı mağduriyeti; Beijer vd. (2018), evsiz kadınlara yönelik erkek şiddetinin türlerini; Ellsworth (2019), evsiz yetişkinlerde sokak suçu mağduriyetini; Alagna vd. (2019), İtalya'nın Palermo şehri özelinde evsizlerin sağlık durumunu incelemiştir.

Çalışma kapsamında yapılan literatür taramasında evsizlerin problemleri üzerine yürütülen çalışmaların genel olarak evsizlerin sağlık problemleri üzerine odaklandığı ortaya çıkmıştır. Bu çalışmada ise son yıllarda evsizlerin sorunlarını konu alan reklam kampanyalarında evsizlere yönelik ne tür mesajların verildiğinin ortaya konulması amaçlanmaktadır. Bu açıdan "Reklam kampanyalarında evsizler nasıl sunulmaktadır?" sorusunun cevaplanması çalışmanın temel amacını oluşturmaktadır. Çalışmada kapsamında ayrıca, reklamlarda evsizlerin nasıl sunulduğunun, hangi konuların ön plana çıkarıldığının ve evsizlere yönelik farkındalığın nasıl oluşturulmaya çalışıldığının açıklanması hedeflenmektedir. Evsizlerin sorunlarını konu alan dünya genelindeki tüm reklam kampanyaları çalışmanın evrenini oluşturmaktadır. Buna karşın çalışmada zaman ve maliyet açısından tüm reklam kampanyalarına ulaşmanın güçlüğünden dolayı çalışmada örneklem kullanılması yoluna gidilmiştir. Bu amaçla Share The World's Resources'ın verilerine göre dünya genelinde evsizlerin yoğun olarak yaşadığı ülkeler içerisinden amaçlı örneklem metodu kullanılarak seçilen 9 ülkeden (Sharing, 2018) ve Türkiye'den evsizlerin sorunlarını konu alan toplam 10 reklam kampanyası nitel araştırma yöntemleri içerisinde yer alan göstergebilimsel analiz yöntemi kullanılarak analiz edilmiştir.

\section{Evsizlerin Yașadığı Temel Sorunlar}

Dünya genelinde 100 milyon civarında evsizin yaşadığı tahmin edilmektedir (Sharing, 2018). Evsizler, dünyanın pek çok farklı bölgesinde çeşitli sorunlar ile yüzleşmektedir. Bu sorunların temelinde de yiyecek ve barınma gelmektedir. Evsizlerin yaşayabilecekleri kalıcı bir barınağa sahip olmamaları, sıcaklık, güvenlik ve sağlık gibi temel ihtiyaçlarının karşılanmasında önemli sorunlar ile karşılaşmalarına yol açmaktadır. Evsizlerin temel sorunları içerisinde yer alan barınma sorunu, evsizlerin belirli bir yerde ikamet etmeler- 
ini engellemektedir. Yani evsizlerin kayda geçmesi güçleşmektedir (Parker ve Albrecht 2012, s.278). Bu süreç evsizlerin posta adreslerinin olmamasına neden olmakta ve kamu hizmetlerinden sistemli bir şekilde yararlanmalarının önüne geçmektedir. Diğer yandan herhangi bir yere kaydı olmayan evsizlerin oy kullanma, emeklilik, sağlık ve eğitim hizmetleri gibi pek çok haktan mahrum olmalarına da yol açabilmektedir. Çoğu durumda evsizler sosyal güvenlik haklarına sahip olamamaktadır. Bu nedenle başta sağlık hizmetleri olmak üzere evsizlerin devlet yardımı almasında önemli engeller ve sınırlııklar ortaya çıkabilmektedir. Karasal iklimin etkili olduğu ülkelerde evsizler için mevcut olan en büyük sorunlarından biri de ısınma sorunu olmaktadır. Kışın dondurucu soğuklarda, evsizler sokaklarda yaşam mücadelesi vermektedir. Bu süreçte devlet tarafından tahsis edilen veya kendi imkânları ile geçici bir barınak bulamayan evsizler, aşırı soğuklar altında ölüm tehlikesi ile yüz yüze gelmekte ve hayatlarını kaybedebilmektedir. Soğuk havalarda kendilerini koruyabilecek kalın giysilere sahip olamayan evsizler de yine ciddi hastalıklara yakalanma riski ile karşı karşıya kalabilmektedir. Evsizler, sağlık açısından da sokaklarda pek çok sorunla mücadele etmektedir. Evsizlerin yiyecek bulmak için kimi zaman çöpleri karıştırmak zorunda kalmaları, sağlıksız beslenmelerine neden olabilmektedir. Evsizler başta bulaşıcı hastalıklar olmak üzere çeşitli hastalıklara yakalanabilmektedir (Raoult 2001, s.77). Özellikle banyo intiyacını periyodik olarak karşılayamayan evsizlerin, hastalıklara yakalanma intimali daha da artabilmektedir.

Evsizlerin yaşadığı alanların gürültülü olması da evsizlerin uykusuz kalmalarına yol açabilmektedir. Evsizler, sağlık hizmetleri alma konusunda da engelle karşılaşabilmektedir (Kushel 2001, s. 200). Bu süreç de evsizlerin tedavi süreçlerini olumsuz yönde etkileyebilmektedir. Evsizlerin sokaklarda yaşaması, belirli bir eşyayı sahiplenmesini zorlaştırmaktadır. Nitekim evsizlerin her zaman taşınması gerekebilmekte ve aynı zamanda açık bir mekanda yaşadığı için sahip olduğu yatakların, giysilerin ve eşyaların muhafazası güçleşebilmektedir. Diğer yandan evsizlerin açık mekanda yaşaması mahremiyet sorunu yaşamalarına da neden olmaktadır. Başta tuvalet ve banyo intiyaçları olmak üzere evsizler pek çok günlük eylemi açık bir ortamda gerçekleştirmek zorunda kalabilmektedir. Benzer şekilde evsizler, yiyecek almak, hazırlamak ve depolamak gibi pek çok farklı sorunla da karşılaşabilmektedir. Yiyeceklerin muhafaza edilmesinin güçlüğü, evsizlerin yiyecek depolamalarını engelleyebilmektedir.

Evsizlere yönelik kimi zaman uygulanan ayrımcılıklar da evsizlerin yaşadığı önemli problemlerden birini oluşturmaktadır. Toplumun bir kısmı tarafından evsizlerin suç ile ilişkilendirilmeleri, evsizlerin yaşadıkları alanda dışlanmalarına yol açabilmektedir. Bazı kişiler tarafından evsizlerin yaşamak için başkalarının eşyalarını çalabileceği ön görülebilmektedir. Bu nedenle evsizler yaşadıkları bölge için potansiyel birer tehlike olarak değerlendirilebilmektedir. Diğer yandan evsizlerin uyuşturucu kaçaklığı, adam kaçırma, tehdit, gasp vb. yasa dışı suçlar ile ilişkilendirilmeleri, evsizlerin halkın düşmanlığına maruz kalmalarına neden olabilmektedir. Tüm bu nedenlerden ötürü evsizler toplumdan dışlanmaktadır (Johnstone 2015, s. 1). Ayrıca kimi evsizlerin yeterli hijyen olanaklarına sahip olamaması ve kıyafetlerinin yırtık ve kirli olması, evsizlerin hastalık taşıdığına yönelik toplum nezdinde algıların oluşmasına da yol açabilmektedir. Böylece insanlar, evsizler ile her türlü iletişimi sonlandırarak, onların bulundukları ye- 
rlere yaklaşmamaya çalışabilmektedir. Evsizlerin dışlanması işe alınmaları sürecinde de önemli bir engel olarak ortaya çıkmaktadır. Evsizlere istihdam konusunda uygulanabilecek muhtemel bir ayrımcılık, evsizlerin ihtiyaçlarını karşılayabilecek gelirden mahrum kalmalarına neden olabilmektedir. Bu aşamada temel sorun insanların zihinlerinde evsizlere yönelik oluşan önyargılardır. Bu önyargıların ortadan kaldırılmaması neticesinde, evsizlere yönelik dışlayıcı tutumun sürmesi, evsizlere yönelik yapılan yardımların azalması ve hatta durması söz konusu olabilmektedir.

\section{Evsizlere Yönelik Yürütülen Yardım Faaliyetleri}

Son yıllarda dünya genelinde sürekli olarak artan evsiz nüfus, çoğu ülkeyi evsizlere yönelik daha duyarlı hale getirmiştir. Bu amaçla pek çok ülke tarafından evsizlere yardım etmek için daha kapsamlı hizmetler sunulmaya başlanmıştır. Bu hizmetler içerisinde, evsizlerin temel intiyaçları içerisinde yer alan yiyecek, barınma, sağlık ve giyecek ön plana çıkmaktadır. Evsizlere yönelik yürütülen yardım faaliyetlerinde devlet kuruluşları önemli rol oynamaktadır. Buna karşın evsizlerin sorunlarına yönelik spesifik yasalar bulunmamaktadır (Akyıldız 2017, s. 67). Ayrıca resmi kurumlar tarafından evsizlere yönelik gerçekleştirilen yardımların yüksek maliyeti, kimi zaman yardımların kalıcı olmasını ve istenilen etkiyi oluşturmasını engelleyebilmektedir. Örneğin, devlet tarafından evsizler yalnızca kışın dondurucu soğukların yaşandığı dönemlerde geçici barınaklara yerleştirilmekte, bunun haricinde barınaklarda sürekli olarak kalmalarına izin verilmemektedir. Nitekim bu alanlar devlet tarafından geçici olarak tahsis edilen kapalı spor salonları gibi mekanlar olmaktadır. Diğer yandan devlet tarafından oluşturulan aşevlerinde evsizlere belirli zamanlarda veya dönemlerde yemek verilebilmektedir. Benzer şekilde de devlet tarafından evsizlerin istihdamına yönelik köklü çalışmalardan ziyade evsizlerin yalnızca günlük ihtiyaçlarını karşılayabilecekleri geçici işlerde istihdam edilebilmeleri sağlanabilmektedir. Dünya genelinde resmi kurumların yanında, evsizliği azaltmak için harekete geçen birçok sivil toplum örgütü ve aktivist girişimler de bulunmaktadır (Yeter 2018, s. 34). Bu yapılar, evsizlerin kendi yeterliliklerini kullanarak evsizlik sorunu çözmeye çalışmaktadır.

Dünya genelinde yardım örgütleri tarafından evsizlere yönelik kapsamlı yardımların gerçekleştirilebilmesi için de kampanyalar düzenlenebilmektedir. Kampanyalar kapsamında evsizlere yönelik farkındalığın oluşturulması ve evsizlere yönelik yardımların yerel düzeyden ulusal boyuta taşınması amaçlamaktadır. Yine bu yapılar tarafından oluşturulan baskı grupları -resmi kanalların evsizlere yönelik daha kapsamlı politikalara yönelmeleri için- faaliyette bulunabilmektedir. Evsizlere yönelik yardım faaliyetlerinde gönüllü organizasyonların yanında kimi zaman dini kurumlar da ön planda olabilmektedir. Resmi kurumlar ve sivil yardım kuruluşları tarafından finanse edilen yardımların dışında evsizlere yönelik gerçekleştirilen bireysel yardımlarda önemli bir yer tutmaktadır. Evsiz olmayan insanlar evsizlere yönelik yiyecek, giyim, kişisel bakım ve diğer yardımları sağlayabilmektedir. Diğer yandan evsizlerin istihdamının sağlanması da önemli bir konu olarak ön plana çıkmaktadır. Bu amaca hizmet eden girişimler de bulunmaktadır (Shier vd. 2012, s. 27). Örneğin evsiz insanlar, para kazanmak için atıkların geri dönüşümünde çalışabilmektedir. Bu kapsamda evsizler çöplerden buldukları iade edilebilir şişeleri ve tenekeleri para kazanmak için geri 
dönüşüm merkezlerine götürebilmektedir.

Evsizlerin intiyaçlarının kendileri tarafından karşılanabilmesini sağlamak amacıyla kâr amacı gütmeyen kuruluşlar da evsizlerin istihdam edilmesinde rol oynayabilmektedir. Evsizlerin istihdam edilmesiyle birlikte yaşadıkları sorunlar önemli ölçüde azalabilmektedir. Özellikle evsizler tarafından günlük intiyaçların karşılanması amacıyla yapılan geçici işlerin yerine sürekli gelir sağlayacak mesai odaklı bir işin başlatılması amaçlanmaktadır. Bu aşamada, evsizlerin istihdamı evsizlerin toplum ile bağlarının güçlenmesinde etkili olabilmektedir. Evsizlerin istihdam edilmesine yönelik yürütülen faaliyetlerin başında sokak gazeteleri satışları bulunmaktadır. Bu süreçte sokak gazeteleri evsiz bireyler tarafından satılan ve esas olarak bu toplulukları desteklemek için üretilmiş gazeteler veya dergileri içermektedir. Gazeteler içerik olarak evsizlik ile ilgili konular hakkında bilgi sağlamakta ve evsiz toplulukların birbirleriyle olan bağlarını güçlendirmeye çalışmaktadır. Bu sistem doğrudan evsiz bireylerin istihdama katılmasını sağlamaktadır. Gazeteler evsizlere ücretsiz olarak sunulmaktadır. Evsizlerin istihdama katılması yaşamlarının farklı bir yönde şekillenmesini sağlayabilmektedir (Montgomery vd. 2016, s. 765). Evsizlerin istihdamıyla birlikte konut probleminin çözülmesine yönelik de son dönemde önemli girişimlere öncelik verilmektedir. Evsizlerin, evsizlik sorununu çözebilmek amacıyla evsiz insanlara uygun fiyatı ve paylaşımlı konut inşa edilmeye yönelik girişimlerde bulunulmaktadır. Evsizler konut konusunda desteklenmektedir (Corinth 2017, s. 69). Evsizlere hem konut hem de istihdam geliri ve iş deneyimi sağlayarak çifte etki oluşturulmaya çalışılmaktadır. Bu amaçla evsizlerin barınacakları evlerin inşa edilmesi sürecinde evsizler bu tür işlerde çalıştırılmaktadır. İnşa edilen konutlarda da evsizler, yemek pişirme, temizlik, alışveriş ve ev bakımı gibi tüm ev işlerinden sorumlu hale getirilmektedir. Böylece evsizlerin sahip olma hissinin geliştirilmesi amaçlanmaktadır. Bu açıdan doğrudan evsizlere katkı sağlamaya çalışan kurumlar bulunmaktadır (Grim 2015, s. 1). Kimi çevreler ise evsizlerin suç olaylarına karışmasının önüne geçebileceği inancıyla evsizlere yönelik yardımların artırımasını tartışmaktadır.

\section{Araștırmanın Yöntemi}

Çalışmada evsizlerin sorunlarını konu alan reklam kampanyalarında evsizlere yönelik ne tür mesajların verildiğinin ortaya konulması amaçlanmaktadır. Çalışma evsizleri konu alan reklam kampanyalarında verilen mesajları açıklaması bakımından önem taşımaktadır. Evsizlerin sorunlarını konu alan dünya genelindeki tüm reklam kampanyaları çalışmanın evrenini oluşturmaktadır. Buna karşın zaman ve maliyet açısından tüm reklam kampanyalarına ulaşmanın güçlüğünden dolayı çalışmada örneklem kullanılmıştır. Bu amaçla Share The World's Resources'ın verilerine göre dünya genelinde evsizlerin yoğun olarak yaşadığı ülkeler içerisinden amaçlı örneklem metodu kullanılarak seçilen 9 ülkeden (Sharing, 2018) ve Türkiye'den evsizlerin sorunlarını konu alan toplam 10 reklam incelenmiştir. Analizlerin on ülke üzerinden yürütülmesi çalışmanın temel sınırııı̆ını oluşturmaktadır. Çalışma kapsamında;

- Reklam kampanyalarında evsizler nasıl sunulmaktadır?

- Reklam kampanyalarında farkındalık oluşturmak amacıyla kitlelere yönelik hangi me- 
sajlar verilmektedir?

- Reklam kampanyalarında evsizlerin sorunları ne şekilde yansıtılmaktadır? sorularına yanıt aranması amaçlanmıştır.

Çalışmada reklam kampanyalarında verilen açık ve gizli mesajların ortaya konulabilmesi için nitel araştırma yöntemleri içerisinde yer alan göstergebilimsel analiz yöntemi kullanıımıştır. Çalışma kapsamında belirlenen 10 ülkenin (Türkiye, Kanada, Ingiltere, Almanya, Brezilya, Arjantin, Avustralya, ABD, Fransa, Rusya) reklam kampanyası, ABD'li dilbilimci Charles William Morris'in göstergebilim anlayışı ışığında analiz edilmiştir.

\section{1. Charles William Morris' in Göstergebilim Anlayıșı}

Göstergebilim, göstergeler yoluyla insanlar tarafından oluşturulan anlamları analiz eden bir bilim dalıdır (Fiske 2017, s. 122). Gösterge ise bir kavramın başka bir kavramın yerine kullanılmasını ifade etmektedir (Rifat 2013, s. 99). Özellikle insanların zihinlerinde belli bir algının şekillenebilmesi için gösterge, soyut kavramların somut kavramlar ile kullanılmasını açıklamaktadır (Çetin ve Sönmez 2015, s. 199). Göstergebilim alanında ilk çalışmalar, İsviçreli dilbilimci Ferdinand de Saussure ve ABD'li dilbilimci Charles SandersPeirce tarafından gerçekleştirilmiştir. İlerleyen dönemde Saussure ve Peirce'in oluşturduğu göstergebilim modelleri temellinde farkı felsefeciler tarafından farklı modeller ortaya çıkarılmıştır. Bunlardan biri de Peirce'in etkisinde kalan ABD'li dilbilimci Charles William Morris (1901-1979) olmuştur. Morris, göstergeler yoluyla meydana getirilen anlamları incelerken sözdizimsel, anlambilimsel ve edimbilimsel olmak üzere üç kavramı ön plana çıkarmıştır. Sözdizimsel boyut, göstergelerin kendi içerisinde biçimsel bağlantılarını; anlambilimsel boyut, göstergeler ile nesne arasındaki bağlantıy; edimbilimsel boyut ise göstergeler ile onları kullanan kişiler arasındaki ilişkiyi ifade etmektedir (Kalkan Kocabay 2008, s. 23).

\section{2. Evsizlere Yönelik Hazırlanan Reklam Kampanyalarının Göstergebilimsel Analizi}

Çalışmanın bu kısmında reklam kampanyalarına ait 10 poster, Morrissin sözdizimsel, anlambilimsel ve edimbilimsel kavramları ışığında analiz edilmiştir.

\section{2. 1. Türkiye'nin Evsizleri Konu Alan Reklam Kampanyası}

Türkiye'de 2018 yılı verilerine göre Aile Çalışma ve Sosyal Hizmetler Bakanlığınna bağlı Çocuk Hizmetleri Genel Müdürlüğü bünyesinde 14.214 çocuk barınmaktadır (CHGM, 2018). Türkiye'nin evsizleri konu alan reklam kampanyası, 2006 yılında Ultra Ajans tarafından hazırlanmıştır. Sözdizimsel açıdan incelendiğinde posterde sokakta uyumakta olan bir evsizin fotoğrafına yer verildiği görülmektedir. Görsel kodlar içerisinde evsizin hemen yanında bulunan boru ve içecek kutusu büyük, evsiz ise küçük olarak sunulmaktadır. Posterin üzerinde "Sokaklar büyük çocuklar küçük" sloganı yer almaktadır. Posterin sağ altında ise "Türkiye'de binlerce çocuk sokaklarda yaşıyor, binlerce tehlikenin içinde büyüyen bu çocuklar, kendilerini koruyabilmek için sokağın sert kurallarıyla tek başlarına mücadele ediyor. Onları gözden çıkarmak zorunda değiliz. Desteğiniz çok önemli” yazılı kodlarına yer verilmektedir. 


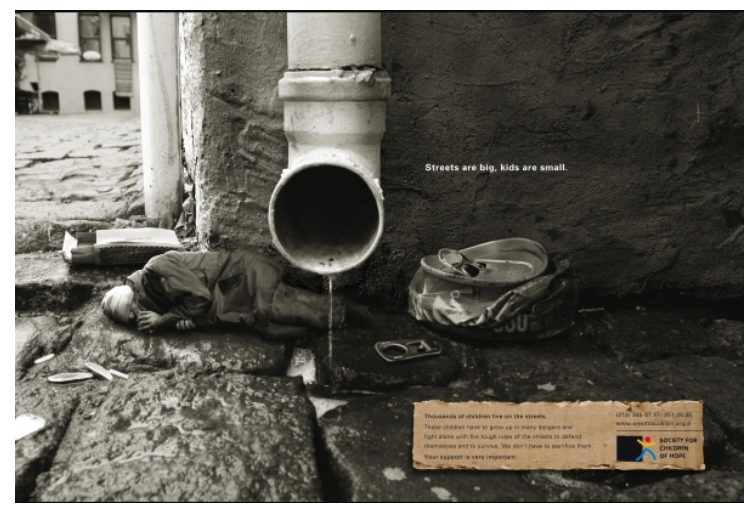

Resim 1. Türkiye'nin Evsizleri Konu Alan Reklam Kampanyası Posteri (Adeevee, 2006a)

Anlambilimsel açıdan incelendiğinde Türkiyesdeki evsiz çocukların reklam kampanyasına konu edildiği görülmektedir. Posterde evsiz çocuğun sokakta küçük olarak yansıtılması ile evsiz çocukların sokaklarda pek çok tehlike ile yüz yüze geldiği mesajı verilmektedir. Posterde yer alan yazılı kodda evsiz çocukların bu tehlikeler ile mücadele edebilecek güçlerinin olmadığı aktarılmaktadır. Poster edimbilimsel olarak analiz edildiğinde, sokağın büyük, çocuğun küçük olarak yansıtılması ile sokaktaki tehlikelere yönelik insanlarda duyarlılık oluşturulmaya çalışılmaktadır. Evsiz, bir gider borusuna oranla daha küçük gösterilerek değersizleştirilmekte, bu şekilde reklamda evsizlerin sorunlarına karşın toplumun evsizlere dikkatini vermediği, sorunlarını ciddiye alınmadığı anlatılmak istenmektedir. Diğer bir deyişle reklamda evsizlerin sorunlarının görmezden gelindiği aktarılmaktadır. Gider borusunda akıntının olmasıyla, evsizlerin zor şartlar altında sokaklarda yaşadığına vurgu yapılmaktadır. Ayrıca bu gösterge üzerinden sokakların evsizler için yaşamaya uygun yerler olmadığı aktarılmak istenmektedir. Kampanya kapsamında kitlelerin doğrudan hüzün duygusuna hitap edilerek, sokak çocuklarına yardım etme konusunda insanlar bilinçlendirilmeye çalışılmaktadır. Posterde Türkiye'de yaşayan evsizlerin sokakta yaşayan bir çocuk üzerinden temsil edilmesi ile Türkiyesnin uzun yıllardır temel sorunlarından biri olarak görülen sokak çocuklarına vurgu yapılması amaçlanmaktadır.

Tablo 1. Türkiye'nin Evsizleri Konu Alan Reklam Kampanyası Posteri

\begin{tabular}{|l|l|}
\hline Sözdizimsel & Evsiz çocuğun caddede uyuması \\
\hline Anlambilimsel & Sokakların evsizlere pek çok tehlike sunması \\
\hline Edimbilimsel & Kitlelerin evsizlere karşı daha duyarlı hale getirilmesi \\
\hline
\end{tabular}

\section{2. 2. Kanada'nın Evsizleri Konu Alan Reklam Kampanyası}

Bir yıl içerisinde ortalama 235.000 kişinin Kanada'da evsizliği yaşadığı rapor edilmektedir (HomelessHub 2016, s. 12). Kanada'nın evsizleri konu alan reklam kampanyası, 2006 yılında Aclc reklam ajansı tarafından hazırlanmıştır. Sözdizimsel açıdan bir evin merdivenlerinde birbirlerine sarılarak oturan evsiz anne ve çocuğunun görseline yer 
verildiği görülmektedir. Görsel kodlar içerisinde anne ve çocuğu soluk renkler içerisinde, saydam olarak yansıtılmaktadır. Posterde "En çok neyi yapmadığımızı görüyoruz" sloganı kullanılmıştır.

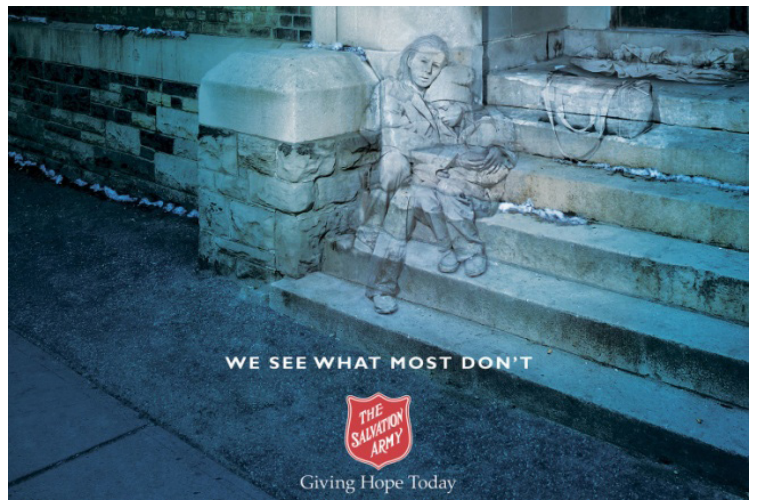

Resim 2. Kanada'nın Evsizleri Konu Alan Reklam Kampanyası Posteri (Adeevee, 2006b)

Poster anlambilimsel olarak analiz edildiğinde, insanların günlük hayatlarında genel olarak evsizlere yeterli yardım yapmadıkları ve onları kimi zaman görmezden geldikleri aktarılmaya çalışılmaktadır. Posterdeki yazılı kod üzerinden günümüzde hala evsizlerin var olmasının temel nedeninin insanların evsizlere yeterli yardım yapmaması olarak gösterilmektedir. Diğer bir ifadeyle evsizlerin yaşadıkları güçlüklerin sorumlularından birinin de evsizlere yardım etmeyenlerin olduğu aktarılmaktadır. Edimbilimsel açıdan incelendiğinde evsizlere yönelik farkındalık oluşturulmasına ve günlük hayatta evsizlerin görmezden gelinmemesine çalışıldığı görülmektedir. Posterde evsizlerin zor durumda oldukları aktarılarak, insanların evsizlere yönelik daha duyarlı olmaları hedeflenmektedir. Bu açıdan ilk reklamda olduğu gibi bu reklamda da insanların hüzün duygularına hitap edilmeye çalışılmaktadır.

Tablo 2. Kanada'nın Evsizleri Konu Alan Reklam Kampanyası Posteri

\begin{tabular}{|l|l|}
\hline Sözdizimsel & Kaldırımda oturan evsizler \\
\hline Anlambilimsel & Evsizlerin görmezden gelinmesi \\
\hline Edimbilimsel & Evsizlere yönelik farkındalık oluşturulması \\
\hline
\end{tabular}

\section{2. 3. İngiltere'nin Evsizleri Konu Alan Reklam Kampanyası}

İngiltere de Shelter'in yapmış olduğu analizde 320.000 kişinin evsiz olarak kaydedildiği ve evsiz sayısının her geçen yıl giderek yükseldiği belirtilmektedir. Diğer bir deyişle İngiltere'de yaşayan her 200 kişiden birinin evsiz olduğu bildirilmektedir (EnglandShelte, 2018). Ingiltere,nin evsizleri konu alan reklam kampanyası, 2006 yılında Saatchi \& Saatchi reklam ajansı tarafından hazırlanmıştır. Sözdizimsel açıdan merdivenin kenarında yere serili bir karton ve üzerinde battaniyenin olduğu görülmektedir. Karton ve battaniyenin yanında bulunan duvarın üstünde de ünlülere ait fotoğraflar yer almaktadır. Posterin sağ alt tarafında “ingiltere'de her on evsizden biri 17 yaşın altında. 
Evsizler evde olmaya başlıyor" yazılı kod bulunmaktadır.

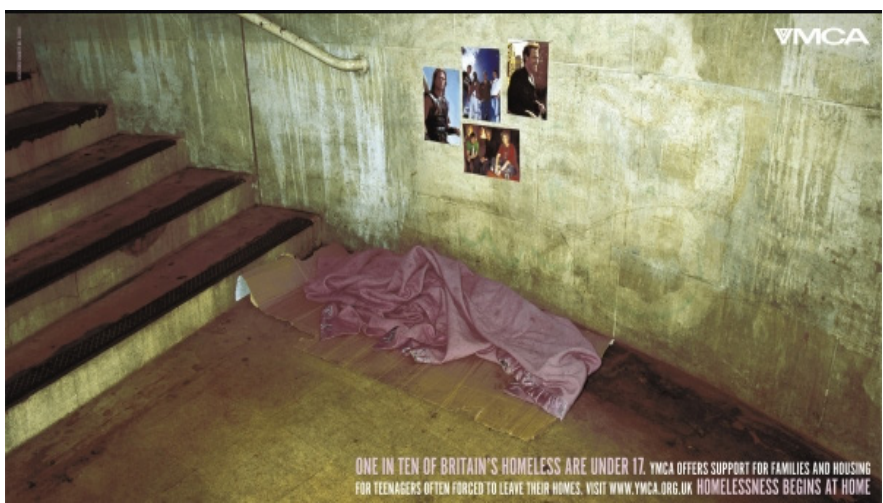

Resim 3. İngiltere,nin Evsizleri Konu Alan Reklam Kampanyası Posteri (Adeevee, 2006c)

Anlambilimsel açıdan incelendiğinde evsizler ile ilgili istatistiki verilere yer verilerek, evsizlerin önemli bir kısmının çocuklardan oluştuğu aktarılmaktadır. Kampanyada yapılacak yardımlar sayesinde evsizlerin de bir evinin olabileceği vurgulanmaktadır. Posterde evsize ait eşyaların gösterilmesi, buna karşın evsize yer verilmemesi ile evsizlerin yapılan yardımlar sayesinde evsiz kalmaktan kurtuldukları algısının oluşturulmaya çalışıldığı görülmektedir. Poster edimbilimsel açıdan analiz edildiğinde, evsizlerin çocuk yaşta olduğu ve yardıma muhtaç kişilerden oluştukları vurgulanarak insanların evsizlere yardım etmesinin sağlandığı görülmektedir. Bu şekilde kitleler evsizlerin önemli bir kısmının çocuk olduğu vurgusu üzerinden, evsizlerin çalışarak kendi hayatlarını oluşturmaları fikrinden uzaklaştırılmaya ve çalışmak için oldukça küçük olan çocuklara yardım etmeleri gerektiği fikrine yöneltilmeye çalışılmaktadır.

Tablo 3. İngiltere,nin Evsizleri Konu Alan Reklam Kampanyası Posteri

\begin{tabular}{|l|l|}
\hline Sözdizimsel & Evsize ait eşyaların kaldırımın kenarında durması \\
\hline Anlambilimsel & Evsizlerin \\
\hline Edimbilimsel & Evsizlerin topluma kazandırılmasında kitlelerin desteğini almak \\
\hline
\end{tabular}

\section{2. 4. Almanya'nın Evsizleri Konu Alan Reklam Kampanyası}

Alman hükümeti ülkedeki evsizlerin sayısının 860 bin civarında olduğunu tahmin etmektedir. Bu sayının yarısını da mülteciler oluşturmaktadır. Illerleyen yıllarda bu sayıda daha da artış beklenmektedir (Deutsche Welle, 2017).Almanya'nın evsizleri konu alan reklam kampanyası, 2006 yılında Aimaq.Rapp.Stolle reklam ajansı tarafından hazırlanmıştır. Sözdizimsel açıdan kapalı bir alanda duvarın kenarında buz şeklinde aktarılan bir evsizin görseline yer verilmektedir. Görsel kodlar içerisinde evsizin üşümekte olduğu mesajı verilmektedir. Posterde yer alan duvarın üzerinde de "sıcaklığa bağış yap" şeklinde reklam kampanyasının sloganı yer almaktadır. 


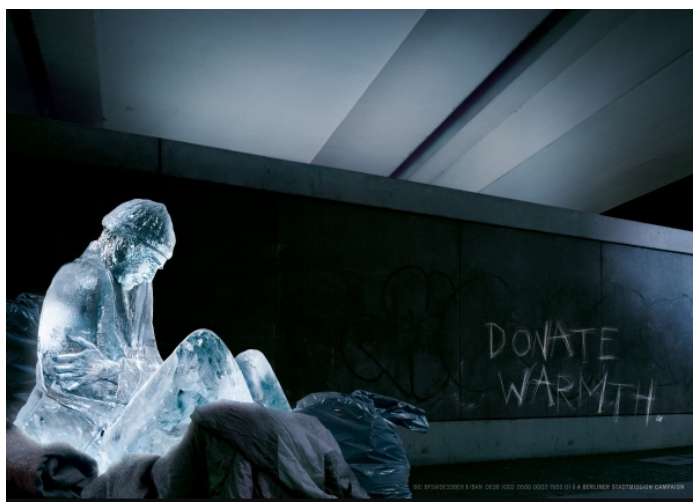

Resim 4. Almanya'nın Evsizleri Konu Alan Reklam Kampanyası Posteri (Adeevee, 2006d)

Poster anlambilimsel açıdan analiz edildiğinde, kampanya kapsamında Almanya'daki evsizlerin en önemli sorunlarından birinin ısınma sorunu olduğu aktarılmaktadır. Karasal iklimin hakim olduğu Almanya'da, evsizlerin kışın zor şartlar altında olduğu ve ısınma problemi çektiği, görsel kodlar içerisinde bir evsizin buz şeklinde gösterilmesi ile aktarılmaya çalışılmaktadır. Posterdeki yazılı kod üzerinden de insanların evsizlere ısınma konusunda yardım etmeleri çağrısında bulunulmaktadır. Posterde açık ve koyu alanlar üzerinden bir kontrast oluşturulmakta, bu şekilde evsizlerin karanlıklar içerisinde yaşadığı ve toplumun tarafından önemsenmediği mesajı verilmektedir. Edimbilimsel açıdan incelendiğinde kitlelerin Almanya`daki insanları evsizlere yardım etme konusunda ikna edebilmek için buzdan bir evsiz görselinin meydana getirildiği görülmektedir. Böylece evsizlerin ısınma konusunda sanılandan çok daha zor bir durumda olduklarına yönelik bir algı oluşturulması amaçlanmaktadır. Kampanyada diğer kampanyalarda olduğu gibi kitleler doğrudan hüzün duygusu üzerinden ikna edilmeye çalışılmaktadır.

Tablo 4. Almanya'nın Evsizleri Konu Alan Reklam Kampanyası Posteri

\begin{tabular}{|l|l|}
\hline Sözdizimsel & Evsizin buz şeklinde gösterilmesi \\
\hline Anlambilimsel & Evsizler soğukla mücadele etmektedir \\
\hline Edimbilimsel & Evsizlere yardım yapılmasını sağlamak \\
\hline
\end{tabular}

\section{2. 5. Brezilya'nın Evsizleri Konu Alan Reklam Kampanyası}

Brezilya'nın önemli şehirlerinden biri olan karnavallarıyla ünlü Rio de Janeiro, ülkede evsizlerin yoğun olarak bulunduğu bir şehir olarak dikkat çekmektedir. Son yıllarda yapılan araştırmalar ülke genelinde evsiz sayısında önemli bir artışın olduğunu ortaya koymaktadır (Rio Times, 2017). Brezilya'nın evsizleri konu alan reklam kampanyası 2007 yılında Giovanni+Draftfcb reklam ajansı tarafından hazırlanmıştır. Sözdizimsel açıdan posterde duvarın kenarında oturan siyahi bir kadın ve küçük bir kız çocuğunun fotoğraflarına yer verildiği görülmektedir. Posterde yer alan siyahi kadının elinde "Cannes'da yaratıcı bir ekibin aslan kazanmasını sağladım" yazılı kodun yer aldığı bir karton bulunmaktadır. Diğer yandan posterin sağ altında "Reklamı hazırlayan, senden 
daha fazla yardıma ihtiyacı olan birçok insan var. Reklamlarınızı oluştururken sorumlu olun" şeklinde yazılı kod yer almaktadır. Anlambilimsel açıdan incelendiğinde posterde evsizler için hazırlanan reklam kampanyalarına yönelik genel bir eleştirinin yapıldığı görülmektedir. Evsizleri konu alan reklam kampanyalarının ödüllendirilmesine rağmen bu reklam kampanyalarının amacına ulaşamadığı ve dolayısıyla evsizlerin sorunlarına çözüm bulunamadığı mesajı verilmektedir. Bu aşamada poster üzerindeki yazılı kodlardan evsizleri konu alan reklamların daha bilinçli bir şekilde hazırlanması gerektiği vurgulanmaktadır.

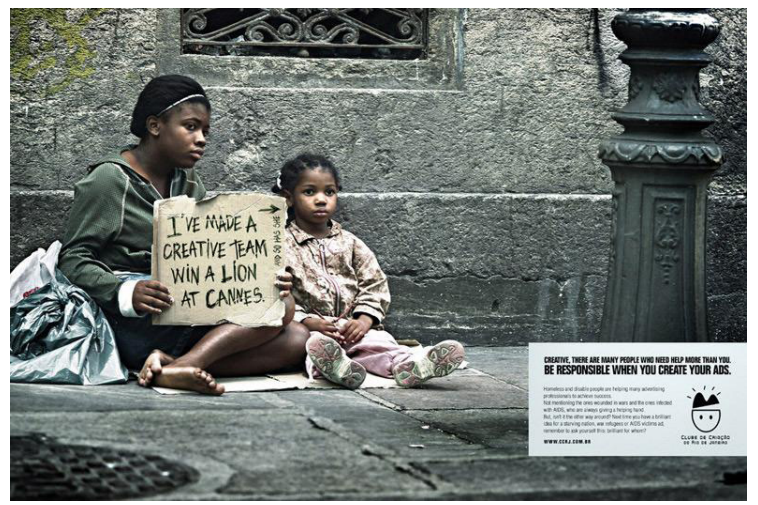

Resim 5. Brezilya'nın Evsizleri Konu Alan Reklam Kampanyası Posteri (ADS, 2007)

Poster edimbilimsel olarak analiz edildiğinde, posterde siyahi evsizlere yer verilmesi ile Brezilya'daki siyahi evsizlere yönelik yardım konusunda duyarlılık oluşturulmaya çalışıldığı görülmektedir. Kampanyada çalışma kapsamında incelenen diğer kampanyalardan farklı olarak, her zaman evsizlere yönelik hazırlanan reklam kampanyalarının amacına ulaşmadığı yönünde kitleler bilgilendirilmekte, insanların reklamları hazırlayanları ödüllendirmekten ziyade evsizlere yardım etmeleri gerektiği vurgulanmaktadır. Böylece evsizlere yönelik farkındalığın arttırılması amaçlanmaktadır.

Tablo 5. Brezilya'nın Evsizleri Konu Alan Reklam Kampanyası Posteri

\begin{tabular}{|l|l|}
\hline Sözdizimsel & Evsiz bir anne ve kızının kaldıııın kenarında durması \\
\hline Anlambilimsel & Evsizlere yönelik yeterli ilginin olmaması \\
\hline Edimbilimsel & Evsizlere yönelik farkındalığın arttırııması \\
\hline
\end{tabular}

\section{2. 6. Arjantin'in Evsizleri Konu Alan Reklam Kampanyası}

Arjantin'de meydana gelen son ekonomik krizden sonra ülkedeki evsiz sayısında önemli bir artışın olduğu kaydedilmektedir (AP, 2019). Arjantin'in evsizleri konu alan reklam kampanyası, 2012 yılında JWT reklam ajansı tarafından hazırlanmıştır. Sözdizimsel açıdan bir merdivenin basamakları üzerinde sırasıyla "ev, pantolon, gömlek, ayakkabı, yemek" "-sız" kelimelerinin yazılı olduğu görülmektedir. Posterin sağ üstünde de "Onlar sadece evsiz değiller. Bağışlayabileceğiniz herhangi bir şeyin önemi olacak" yazılı kodu yer almaktadır. 


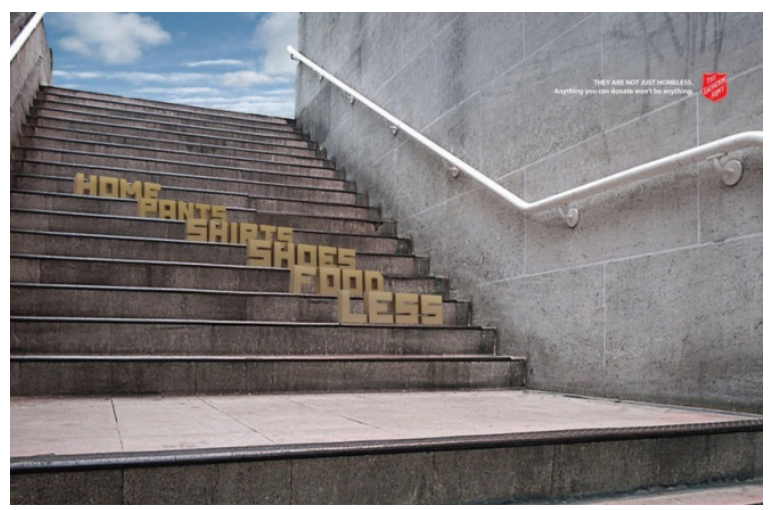

Resim 6. Arjantin'in Evsizleri Konu Alan Reklam Kampanyası Posteri (ADS, 2012)

Anlambilimsel açıdan analiz edildiğinde, posterde evsiz görseline yer verilmeden doğrudan yazılı kodlar üzerinden kampanyan mesajının aktarılmaya çalışıldığı görülmektedir. Posterdeki yazılı kodlar, doğrudan Arjantin'deki evsizlerin temel ihtiyaçlarından olan yemek ve giyeceği yansıtmaktadır. Arjantin'deki evsizlerin temel sorunun yalnızca ev olmadığı aynı zamanda yiyecek ve giyim konusunda da ciddi sıkıntılar içerisinde oldukları aktarılmaktadır. Edimbilimsel açıdan incelendiğinde, kampanya kapsamından insanların evsizlere karşı daha duyarlı hale getirilmesinin amaçlandığı görülmektedir. Posterde yer alan yazılı ve görsel kodlar üzerinden insanların yapacakları en ufak bir bağışın bile evsizler için değer taşıdığına vurgu yapılmaktadır. Bu açıdan insanların yardım yapma konusunda daha bilinçli hareket etmesi ve evsizlere yardım konusunda duyarlılık oluşturulması amaçlanmaktadır.

Tablo 6. Arjantin'in Evsizleri Konu Alan Reklam Kampanyası Posteri

\begin{tabular}{|l|l|}
\hline Sözdizimsel & Üç boyutlu kelimelerin merdivenin üzerinde durması \\
\hline Anlambilimsel & Evsizlerin temel ihtiyaçlarının karşılanamaması \\
\hline Edimbilimsel & Evsizlere yönelik bağışların arttırıımasının amaçlanması \\
\hline
\end{tabular}

\section{2. 7. Avustralya'nın Evsizleri Konu Alan Reklam Kampanyası}

Avustralya Konut ve Kentsel Araştırma Enstitüsü (AHURI) tarafından yayınlanan bir raporda evsizlerin, ülkenin iki büyük kenti Sydney ve Melbourne'de yoğunlaştığı ortaya konulmuştur (The Guardian, 2019). Avustralya'nın evsizleri konu alan reklam kampanyası, 2013 yılında Ursa reklam ajansı tarafından hazırlanmıştır. Sözdizimsel açıdan Noel ışıklarıyla süslenmiş bir bankın fotoğrafına yer verildiği görülmektedir. Görsel kodlar içerisinde havanın karanlık olduğu aktarılmaktadır. Posterin sağ üstünde de "Noel evsizlere hitap ediyor" yazılı kodu yer almaktadır. 


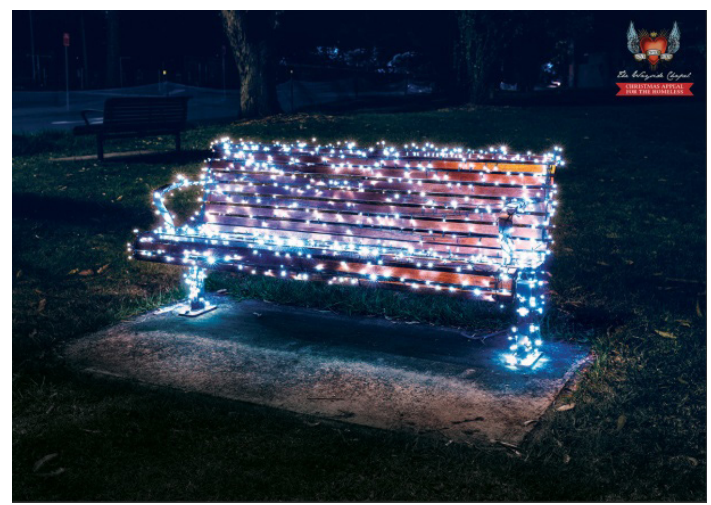

Resim 7. Avustralya'nın Evsizleri Konu Alan Reklam Kampanyası Posteri (ADS, 2013)

Anlambilimsel açıdan incelendiğinde, posterde yılbaşı özelinde evsizlere yönelik yardımın konu edinildiği görülmektedir. Avustralya'da yılbaşında insanların birbirlerine yardım ettiği vurgulanarak, yılbaşında özellikle evsizlere yardım edilmesi gerektiği aktarılmaktadır. Posterde yer alan bank görseli evsizleri temsil eden bir metonimi olarak ön plana çıkarılmıştır. Bankın ışıklarla süslendirilmesi ile evsizlere yılbaşında yapılacak olan yardımların evsizlerin daha iyi bir yaşam elde etmesini sağlayacağı mesajı verilmektedir. Poster edimbilimsel olarak analiz edildiğinde, kampanya kapsamında insanların yılbaşındaki yardımlaşma duygusundan yararlanarak evsizlere yardım etmelerinin sağlanmaya çalışıldığı görülmektedir. Bu açıdan evsizlere yönelik yardım sağlama sürecinde, yılbaşı insanları harekete geçirebilecek bir güç olarak değerlendirilmiş ve insanların evsizlere yapacakları yardımlar ile evsizlerin de yaşamında önemli bir değişimin olabileceği aktarılmıştır.

Tablo 7. Avustralya'nın Evsizleri Konu Alan Reklam Kampanyası Posteri

\begin{tabular}{|l|l|}
\hline Sözdizimsel & Bankın ışıklarla donatılması \\
\hline Anlambilimsel & Yılbaşında evsizlere yardım edilmesi \\
\hline Edimbilimsel & Evsizlere yönelik yardımın teşvik edilmesi \\
\hline
\end{tabular}

\section{2. 8. ABD'nin Evsizleri Konu Alan Reklam Kampanyası}

ABD'de Konut ve Kentsel Gelişim Bakanlığı'nın hazırladığı bir rapora göre 2018 yılı içerisinde 553.000'e yakın insanın evsiz olduğu ortaya konulmuştur (Novoco 2018, s. 1). ABD'nin evsizleri konu alan reklam kampanyası, 2014 yılında Saatchi \& Saatchi reklam ajansı tarafından hazırlanmıştır. Sözdizimsel açıdan yere bir insan resminin çizildiği görülmektedir. İnsan resminin ağız bölümünde de çöplerin olduğu aktarılmaktadır. Posterde yer alan resmin üzerine de "Sokakta yemek güzel değil. New York’taki açlığın silinmesine yardım edin” şeklinde reklam kampanyasının sloganının yazıldığı görülmektedir. 


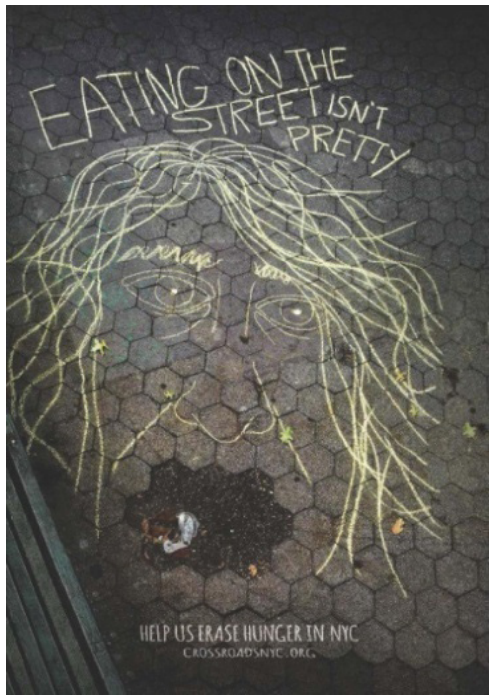

Resim 8. ABD’nin Evsizleri Konu Alan Reklam Kampanyası Posteri (ADS, 2014)

Poster anlambilimsel olarak analiz edildiğinde, posterde evsizlerin nasıl karınlarını doyurduğuna dair bir farkındalık oluşturulmasının amaçlandığı görülmektedir. Posterdeki görsel kodlarda evsizin ağzında çöplerin gösterilmesi ile ABD'de yaşayan evsizlere yönelik hüzün duygusunun ön plana çıkarılmaya çalışıldığı görülmüştür. Evsizlerin yalnızca ev bulma konusunda problem yaşamadığı aynı zamanda yiyecek bulma konusunda da önemli sıkıntılar ile karşılaştıkları insanlara aktarılmaya çalışılmaktadır. Bu şekilde dünyanın en büyük ekonomik gücüne sahip olmasına karşın ABD'de evsizlik probleminin sürdüğü ve her evsiz için düzenli olarak yiyecek yardımı yapılmadığına vurgu yapılmaktadır. Edimbilimsel açıdan incelendiğinde, ABD,deki evsizlerin en temel problemlerinden birinin yiyecek bulma olduğu üzerinde durulmaktadır. Kampanya kapsamında evsizlerin yiyeceklerini genel olarak çöplerden ve çevreye atılan yemek artıklarından sağladıklarına yönelik farkındalık oluşturulması amaçlanmaktadır. Bu yolla insanların, evsizlere yönelik yemek yardımı yapmasının teşvik edilmeye çalışıldığı görülmektedir.

Tablo 8. ABD'nin Evsizleri Konu Alan Reklam Kampanyası Posteri

\begin{tabular}{|l|l|}
\hline Sözdizimsel & Sokağa çizilmiş bir evsiz resmi \\
\hline Anlambilimsel & Evsizlerin zor şartlarda yiyecek bulması \\
\hline Edimbilimsel & Evsizlere yönelik yiyecek yardımını teşvik etmek \\
\hline
\end{tabular}

\section{2. 9. Fransa'nın Evsizleri Konu Alan Reklam Kampanyası}

Fransa'da yapılan araştırmada ülkenin başkenti Paris'te evsiz sayısında ciddi bir artışın olduğu ortaya konulmuştur (The Local, 2019). Fransa'nın evsizleri konu alan reklam kampanyası, 2017 yılında Altmann + Pacreau reklam ajansı tarafından hazırlanmıştır. Sözdizimsel açıdan bir anne ve kızının evsiz bir anne ve kızına yardım ettiği gösterilme- 
ktedir. Görsel kodlar içerisinde posterde yardımda bulunan anne ve kız ile yardım alan anne ve kız fotoğraflarının aynı olduğu dikkat çekmektedir. Posterin sağ üstünde de "Dışarıda kalmak herhangi birinin başına gelebilir. Bağış yap" reklam kampanyasının sloganına yer verilmektedir.

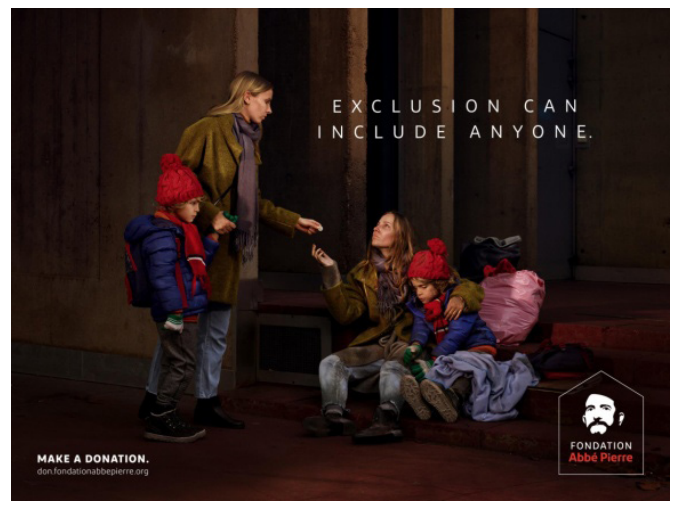

Resim 9. Fransa'nın Evsizleri Konu Alan Reklam Kampanyası Posteri (ADS, 2017)

Anlambilimsel açıdan incelendiğinde, posterde herkesin bir gün evsiz kalabileceği vurgusu üzerinden insanların evsizlere yardım etmesinin amaçlandığı görülmektedir. Posterde herhangi bir ailenin yaşayacağı problemler nedeniyle evsiz kalabileceği ve insanların yardımlarına intiyaç duyabileceği aktarılmaktadır. Böylece insanların aklına evsiz kalabilecekleri intimali getirilerek, evsizlere yönelik daha duyarlı olunmasının sağlanmaya çalışıldığı görülmektedir. Poster edimbilimsel olarak analiz edildiğinde, posterde doğrudan insanların evsizler ile empati kurmasının amaçlandığı görülmektedir. İnsanların evsizlerin hissettikleri duyguları hissetmesi ve böylece onların yaşadıkları problemleri akıllarına getirmeleri istenmektedir. Bu yolla posterdeki slogan üzerinden de belirtildiği gibi insanların evsizlere yardım etmesi amaçlanmaktadır. Diğer bir deyişle poster üzerinden inşa edilen empatinin, doğrudan evsizlere yönelik bağış haline dönüşmesi planlanmaktadır.

Tablo 9. Fransa'nın Evsizleri Konu Alan Reklam Kampanyası Posteri

\begin{tabular}{|l|l|}
\hline Sözdizimsel & Anne ve çocuğunun evsiz olarak sunulması \\
\hline Anlambilimsel & Herkesin evsiz olabileceği intimali \\
\hline Edimbilimsel & Kitlelerin evsizlere yönelik empati kurmasının sağlanması \\
\hline
\end{tabular}

\section{2. 10. Rusya'nın Evsizleri Konu Alan Reklam Kampanyası}

2017 yılı içerisinde Rusya'da 5 milyon civarında evsizin olduğu belirtilmiştir. Bu rakam pek çok ülkenin nüfusundan daha fazla bir sayıya denk gelmektedir (Euromaidan, 2017). Rusya'nın evsizleri konu alan reklam kampanyası, 2019 yılında Kollegi reklam ajansı tarafından hazırlanmıştır. Sözdizimsel açıdan binaların altında gökyüzünün gösterilmekte olduğu görülmektedir. Posterde gökyüzüne doğru "Yerleşim planını hiç 
kimse seçmedi” şeklindeki reklam kampanyasının sloganı aktarılmaktadır. Posterin sol altında da "Her yıl yüzlerce insan Saint Petersburg sokaklarında yaşıyor. Evsiz olmanın ana nedenleri: \% 42 - iş arama yeri değiştirme, \% 28 aile sorunları, \% 16 gerçek emlak dolandırıcılığı" şeklinde yazılı kodları yer almaktadır.

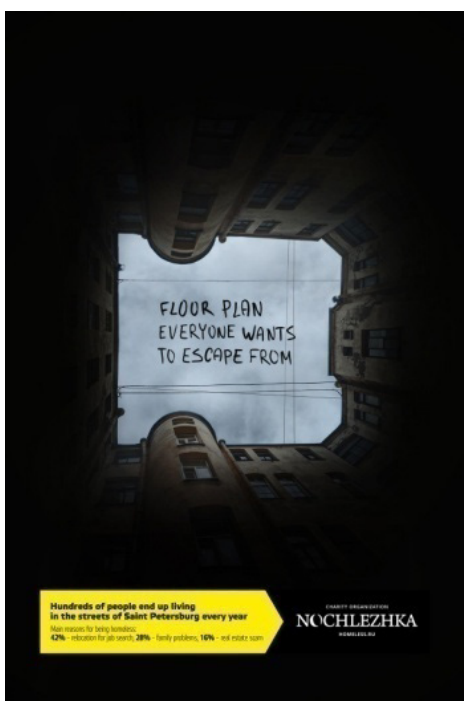

Resim 10. Rusya'nın Evsizleri Konu Alan Reklam Kampanyası Posteri (ADS, 2019)

Poster anlambilimsel olarak analiz edildiğinde, evsizlerin Rusya'da yaşadıkları zor yaşantının ön plana çıkarılmaya çalışıldığı görülmektedir. Posterde binaların arasından gökyüzüne doğru bir açıdan bakılması ile evsizlerin diğer insanlardan farklı olarak çatısı olmayan sokaklarda yaşamlarını sürdürdükleri mesajı verilmeye çalışılmaktadır. Posterdeki slogan üzerinden de değerlendirildiğinde bu yaşantının evsizler tarafından değil, onların başlarına gelen olaylar nedeniyle yaşandığı aktarılmak istenmektedir. Yüksek binalarla çevrilmiş gökyüzü ile evsizlerin sorunlar ile kuşatıldığı ve bu sorunlara çözüm bulunamadığı için özgürlüklerini kaybetmiş mahkumlar gibi yaşadıkları mesajı verilmektedir. Edimbilimsel açıdan incelendiğinde, insanların hangi durumlarda evsiz duruma düştükleri istatistiki veriler üzerinden aktarılarak, Rusya>daki insanlar evsizlere yönelik bilinçlendirilmeye çalışılmaktadır. Böylece Rusya,da insanların evsiz olmalarının kendi tercihleri olmadığı mesajı verilmekte ve evsizlerin yardıma ihtiyacı olduğu vurgusu yapılmaktadır. Evsizlerin, yaşadıkları sorunlar nedeniyle mağduriyet yaşadıkları aktarılmakta ve evsizlere yönelik yardım odaklı farkındalık meydana getirilmeye çalışılmaktadır.

Tablo 10. Rusya'nın Evsizleri Konu Alan Reklam Kampanyası Posteri

\begin{tabular}{|l|l|}
\hline Sözdizimsel & Apartmanların arasından gökyüzünün gösterilmesi \\
\hline Anlambilimsel & Evsizliğin nedenlerinin ortaya konulması \\
\hline Edimbilimsel & Evsizlere karşı farkındalık oluşturmak \\
\hline
\end{tabular}




\section{Sonuc}

Reklam kampanyalarının tümünde yaratıcı reklam stratejisi olarak duygusal stratejinin kullanıldığı görülmektedir. Görsel ve yazılı kodlar üzerinden evsizlerin yaşadığı olumsuz şartlar kampanyalara yansıtılarak duygulara yönelinmiş ve bu şekilde kitlelerin evsizlere yardım etmelerinin sağlanması amaçlanmıştır. Reklamlarda evsizlerin soğuk havada yaşamaları ve yiyecek bulma konusunda güçlük çekmeleri konu edinilmektedir. Bu aşamada kampanyalarda genel olarak zor şartlar altında yaşayan evsizlerin görsellerine (veya temsillerine) yer verilmektedir. Bazı kampanyalarda da evsizlerin yaşadığı sokak köşeleri gösterilmekte ve bu köşelerde evsizliği çağrıştıran bank, karton veya sokağa çizilen şekil üzerinden evsizlerin yaşadığı zor şartlara vurgu yapılmaya çalışılmaktadır. Reklam kampanyalarında ekonomik eşitsizliklere değinilmeden yalnızca evsizlerin yaşadığı zorluklar ön plana çıkarılmaktadır. Bu açıdan kampanyalarda sosyal adaletsizliğin eleştirisine yönelik herhangi bir mesaja yer verilmediği ortaya çıkmaktadır. Reklamlardaki ana strateji, evsizlerin yaşadığı sorunların kitlelere belirli temsiller üzerinden aktarılması ve bu şekilde evsizlere yönelik kamuoyunda farkındalık oluşturulması üzerine temellenmektedir.

Reklam kampanyalarında evsizler, toplum tarafından önemsenmeyen kişiler olarak temsil edilmektedir. Bu aşamada kampanyalarda toplumun evsizlerin yaşadıkları sorunlara duyarlı olmadığı, bu nedenle evsizlerin sorunlarının çözüme kavuşturulamadığı mesajı verilmeye çalışılmaktadır. Evsizlerin ısınma ve yiyecek gibi temel ihtiyaçlarını bile karşılamakta güçlük çektiği kampanyalarda kitlelere aktarılmaktadır. Böylece kitlelerin evsizlerin yaşadığı sorunların ciddiyetinin farkına varmaları ve evsizlere yönelik daha duyarlı davranmaları amaçlanmaktadır.

Çalışmada incelenen 10 ülkenin evsizleri konu alan reklam kampanyalarında önemli benzerliklerin olduğu gözlemlenmiştir. Reklam kampanyalarında genel olarak kitleleri, evsizlere yardım etmeye teşvik etmek için hüzün duygusunun ön plana çıkarıldığı saptanmıştır. Kampanyalarda insanların hüzün duygularına hitap edilerek, evsizlerin yaşadıkları sorunlar ile ilgili olarak duyarlılık oluşturulması amaçlanmıştır. Kampanyaların genelinde evsizlerin kalacak bir evlerinin olmaması temel sorun olarak öne çıkarılırken, bunun yanında, yiyecek ve giyecek sorunlarına da vurgu yapılmıştır. Böylece kampanyalarda insanların, temel intiyaçlar olan yiyecek ve giyecek konusunda evsizlere yardım etmelerinin teşvik edilmesi amaçlanmıştır. Diğer yandan kampanyaların mesajlarında ülkelere göre önemli farklılıklarında olduğu görülmüştür. Örneğin, Türkiye'nin reklamında sokaklarda yaşayan evsiz çocuklar, Brezilya'nın reklamında da evsiz siyahiler ön plana çıkarılmıştır. Böylece Türkiye'de evsizler konusunda yaşanan temel sorunun evsiz çocuklar, Brezilya'da da evsiz siyahiler olduğu üzerinde bir algı oluşturulması amaçlanmıştır. Evsizlerin sorunları ile ilgili insanları sorumlu tutan iki ülke Kanada ve Brezilya olmuştur. Kanada'nın reklamında evsizlere yardım etmeyen insanlar, Brezilya'nın reklamında ise reklamcılar, evsizlerin yaşadıkları sorunlar ile ilgili sorumlu tutulmuştur. Kampanyalar içerisinde yapılan yardımlar ile evsizlerin hayatlarında olumlu değişimin olduğunu aktaran tek ülke ise İngiltere olmuştur. Reklamda pozitif bir strateji kullanılmış ve yardım edildiği taktirde evsizlerin sorunlarına çözüm bulunabileceği aktarılmıştır. Buna karşın diğer reklamlar yalnızca evsizlerin yaşadığı sorunları yansıtma yoluna gitmiştir. İnsanların evsiz olmasına yol açan ned- 
enleri açıklayan tek ülke ise Rusya, insanların doğrudan evsizler ile empati kurmasını amaçlayan tek ülkenin ise Fransa olduğu ortaya çıkarılmıştır.

Evsizlere yönelik duyarlılık oluşturabilmek için evsizlerin reklamların bir kısmında fiktif bir şekilde temsil edildiği görülmüştür. Örneğin Almanya'nın reklamında buz şeklinde, Kanada'nın reklamında ise saydam şekilde evsizler temsil edilmiştir. Bu şekilde reklam mesajının daha dikkat çekici ve akılda kalıcı olması amaçlanmıştır. Reklamların bir kısmında da evsizlere ait görsellere veya fotoğraflara yer verilmeden evsizlerin sorunları sunulmuştur. Örneğin Avustralya'nın reklamında bank metonimi, ABD’nin reklamında yere çizilen bir insan tasviri üzerinden evsizlerin sorunu kitlelere aktarılmıştır. Böylece kampanyalarda evsizlere yönelik kitlelerin dikkati çekilerek, insanların evsizlere yönelik yardım konusunda daha bilinçli olarak hareket etmesi amaçlanmıştır. Çalışmada incelenen reklam kampanyalarının kamuoyu genelinde evsizlere yönelik farkındalık oluşturması konusunda önem taşıdığı düşünülmektedir. Buna karşın evsizlere yönelik hazırlanan reklam kampanyalarında;

- Evsizlerin yaşadığı sorunların birebir evsizlerin sözleri üzerinden aktarılmasının,

- Evsizlerin sosyal güvenlik haklarının iyileştirilmesinde atılan adımlara ve yardımlar sayesinde yaşamlarında olumlu yönde değişim yaşanan evsizlere yer verilmesinin,

- Evsizlerin sağlık ve eğitim gibi temel konularda yaşadıkları sorunların istatistiki veriler üzerinden belirtilmesinin,

- Evsizlere yapılacak yardımlar ile evsizlerin yaşamlarında ne gibi olumlu gelişmelerin yaşanabileceğinin açıklanması,

- Evsiz sayısında azalma yaşanan Finlandiya'daki gibi evsizlere yönelik uygulanan başarılı çalışmaların örnek olarak sunulması ile kampanyaların evsizlere yönelik yardım konusunda daha fazla duyarlııı oluşturabilecekleri düşünülmektedir.

Çalışma kapsamında yalnızca 10 reklam kampanyasının incelenmesi çalışmanın temel sınırıı̆ı̆ını oluşturmaktadır. Diğer yandan çalışma, evsizleri konu alan reklam kampanyalarının kitleler üzerinde nasıl bir etki oluşturduğunu ampirik açıdan ortaya koyamamaktadır. Bu nedenle, gelecek çalışmaların evsizlerin sorunları üzerine hazırlanan reklam kampanyalarının kitleler üzerindeki etkisini ortaya çıkaran uygulamalı saha çalışmalarına yönelmesinin alana katkı sağlayacağı düşünülmektedir.

\section{Kaynakça}

Adeevee (2006a). Türkiye'nin Reklam Kampanyası. 26 Haziran 2019 tarihinde https://www. adeevee. com /2006 /04/ children- of-hope -society- homeless- children-awareness- drain-pipeprint/ adresinden edinilmiştir.

Adeevee (2006b). Kanada'nın Reklam Kampanyası. 26 Haziran 2019 tarihinde https:/ /www. adeevee. com/ 2006/ 09/ the- salvation -army- homeless- awareness- bench- alleyway- stairsoutdoor/ adresinden edinilmiştir.

Adeevee (2006c). İngiltere'nin Reklam Kampanyası. 26 Haziran 2019 tarihinde https:// www. adeevee.com/ 2006/04/ ymca- help-for- the- homeless- arsenal- will- young- outdoor/ adresinden edinilmiştir. 
Adeevee (2006d). Almanya'nın Reklam Kampanyası. 26 Haziran 2019 tarihinde https:// www. adeevee. com/ 2006/03/berliner- stadtmission- evangelische- kirche- ekbo- homeless- charityright- side-lying- down- left- side- print/ adresinden edinilmiştir.

Alagna, E., Santangelo, O. E., Raia, D. D., Gianfredi, V., Provenzano, S., \& Firenze, A. (2019). Health status, diseases and vaccinations of the homeless in the city of Palermo, Italy. Annali di Igiene: Medicina Preventiva e di Comunita, 31(1), 21-34.

ADS (2007). Brezilya'nın Reklam Kampanyası. 26 Haziran 2019 tarihinde https://www .adsoftheworld. com/ media/ print/ creative_team adresinden edinilmiştir.

ADS (2012). Arjantin'in Reklam Kampanyası. 26 Haziran 2019 tarihinde https://www. adsoftheworld. com/ media/ print/salvation_army_letters_3 adresinden edinilmiştir.

ADS (2013). Avustralya'nın Reklam Kampanyası. 26 Haziran 2019 tarihinde https:// www. adsoftheworld. com/ media/ outdoor/ the_ wayside_chapel_a_brighter_christmas adresinden edinilmiştir.

ADS (2014). ABD'nin Reklam Kampanyası. 26 Haziran 2019 tarihinde https:// www. adsoftheworld. com/ media/ outdoor/ crossroads_street_fare _4 adresinden edinilmiştir.

ADS (2017). Fransa'nın Reklam Kampanyası. 26 Haziran 2019 tarihinde https:// www. adsoftheworld. com/media /outdoor/ fondation_abbe_ pierre_exclusion_can_include _anyone 3 adresinden edinilmiştir.

ADS (2019). Rusya'nın Reklam Kampanyası. 26 Haziran 2019 tarihinde https: //www. adsoftheworld. com/ media/ print /nochlezhka_floor_plan_of_homeless adresinden edinilmiştir.

Akyıldız, Y. (2017). Dünyada ve Türkiye'de evsizlik sorunu ve çeşitli uygulamalar, LAÜ Sosyal Bilimler Dergisi, (VIII-I): 67-91.

Alperstein, G., Rappaport, C., \& Flanigan, J. M. (1988). Health problems of homeless children in New York City. American Journal of Public Health, 78(9), 1232-1233.

Anooshian, L. J. (2005). Violence and aggression in the lives of homeless children. Journal of Family Violence, 20(6), 373-387.

AP (2019). Arjantin'de Evsizler. 9 Temmuz 2019 tarihinde https:// www. apnews. com/ acaae1 5e213348 8aa41c8 bef7a1f6147 adresinden edinilmiştir.

Bassuk, E. L., \& Beardslee, W. R. (2014). Depression in homeless mothers: addressing an unrecognized public health issue. American Journal of Orthopsychiatry, 84(1), 73.

Beijer, U., Scheffel Birath, C., DeMartinis, V., \& af Klinteberg, B. (2018). Facets of male violence against women with substance abuse problems: women with a residence and homeless women. Journal of Interpersonal Violence, 33(9), 1391-1411.

Benda, B. B. (2005). A Study of substance abuse, traumata, and social support systems among homeless veterans. Journal of Human Behavior in the Social Environment, 12(1), 59-82.

Breton, M., \& Bunston, T. (2009). Physical and sexual violence in the lives of homeless women. Canadian Journal of Community Mental Health, 11(1), 29-44.

Burke, C., Johnson, E. E., Bourgault, C., Borgia, M., \& O'Toole, T. P. (2013). Losing work: regional unemployment and its effect on homeless demographic characteristics, needs, and health care. Journal of Health Care for the Poor and Underserved, 24(3), 1391-1402.

Cheng, L. C., \& Yang, Y. S. (2010). Homeless problems in Taiwan: looking beyond legality toward social issues. City, Culture and Society, 1(3), 165-173.

CHGM (2018). Çocuk Hizmetleri Genel Müdürlüğü. 9 Temmuz 2019 tarihinde https:// www. 
ailevecalisma. gov. tr/ media /5864/ chgm- 2018-istatistik. pdf adresinden edinilmiştir.

Chiu, S., Redelmeier, D. A., Tolomiczenko, G., Kiss, A., \& Hwang, S. W. (2009). The Health of homeless immigrants. Journal of Epidemiology \& Community Health, 63(11), 943-948.

Corinth, K. (2017). The Impact of permanent supportive housing on homeless populations. Journal of Housing Economics, 35, 69-84.

Çetin, M., \& Sönmez, E. E. (2015). Sosyal temsil kuramı bağlamında kurumsal reklamlar: Türk hava yolları örneği, İletişim Kuram ve Araştırma Dergisi, 1(39), 191-207.

Deutsche Welle (2017). Almanya'daki Evsizler. 9 Temmuz 2019 tarihinde https:// www. dw. com/ en/ germany -150 -percent -rise -in- number -of-homeless -since-2014 /a-41376766. pdf adresinden edinilmiştir.

Ellsworth, J. T. (2019). Street Crime victimization among homeless adults: a review of the literature. Victims \& Offenders, 14(1), 96-118.

England Shelter (2018). İngiltere'deki Evsizler. 9 Temmuz 2019 tarihinde https:// england. shelter. org.uk/media/ press_releases/ articles/320,000_people_ in_britain_are_now_ homeless,_as_numbers_ keep_ rising adresinden edinilmiştir.

Euromaidan (2017). Rusya'daki Evsizler. 9 Temmuz 2019 tarihinde http:// euromaidanpress. com /2017/07/08/ russia-has- as-many- as-5- million- homeless- not- the- 64000 - rosstatreports- euromaidan-press/ adresinden edinilmiştir.

Fiske, J. (2017). İletişim çalışmalarına giriş. S. İrvan (Çev.), 5. Basım, Ankara: Bilim ve Sanat Yayınları.

Gaetz, S. (2004). Safe streets for whom? homeless youth, social exclusion, and criminal victimization. Canadian Journal of Criminology and Criminal Justice, 46(4), 423-456.

Galaif, E. R., Nyamathi, A. M., \& Stein, J. A. (1999). Psychosocial predictors of current drug use, drug problems, and physical drug dependence in homeless women. Addictive Behaviors, 24(6), 801-814.

Grim, E. C., Gultekin, L. E., \& Brush, B. L. (2015). Do policies aimed toward the homeless help families? the detroit experience. Journal of Policy Practice, 14(1), 1-13.

Hanratty, M. (2017). Do Local economic conditions affect homelessness? impact of area housing market factors, unemployment, and poverty on community homeless rates. Housing Policy Debate, 27(4), 640-655.

Harding, R., \& Hamilton, P. (2008). Working girls: abuse or choice in street-level sex work? a study of homeless women in Nottingham. British Journal of Social Work, 39(6), 1118-1137.

Homeless Hub (2016). Kanada'da Evsizlik. 9 Temmuz 2019 tarihinde https:// homelesshub. ca/ sites/ default/ files/ SOHC16_ final_ 200ct2016.pdf adresinden edinilmiştir.

İlhan, N., \& Ergün, A. (2010). Evsizler ve toplum sağlığı, Sosyal Politika Çalışmaları Dergisi, 20(20), 79-90.

Jasinski, J. L. (2010). Hard lives, mean streets: violence in the lives of homeless women, The United States: UPNE.

Johnstone, M., Jetten, J., Dingle, G. A., Parsell, C., \& Walter, Z. C. (2015). Discrimination and well-being amongst the homeless: the role of multiple group membership. Frontiers in Psychology, 6, 739, 1-9.

Kalkan Kocabay, H. (2008). Tiyatroda göstergebilim. İstanbul: E Yayınları.

Kurtz, P. D., Jarvis, S. V., \& Kurtz, G. L. (1991). Problems of homeless youths: empirical findings 
and human services issues. Social Work, 36(4), 309-314.

Kushel, M. B., Vittinghoff, E., \& Haas, J. S. (2001). Factors associated with the health care utilization of homeless persons. Jama, 285(2), 200-206.

Lee, B. A., \& Schreck, C. J. (2005). Danger on the streets: marginality and victimization among homeless people. American Behavioral Scientist, 48(8), 1055-1081.

Matheson, F. I., Devotta, K., Wendaferew, A., \& Pedersen, C. (2014). Prevalence of gambling problems among the clients of a Toronto homeless shelter. Journal of Gambling Studies, 30(2), 537-546.

Montgomery, A. E., Szymkowiak, D., Marcus, J., Howard, P., \& Culhane, D. P. (2016). Homelessness, unsheltered status, and risk factors for mortality: findings from the 100000 homes campaign. Public Health Reports, 131(6), 765-772.

Moore, H., Benbenishty, R., Astor, R. A., \& Rice, E. (2018). The Positive role of school climate on school victimization, depression, and suicidal ideation among school-attending homeless youth. Journal of School Violence, 17(3), 298-310.

Novoco (2018). ABD'deki Evsiz Sayısı. 9 Temmuz 2019 tarihinde https:// www. novoco. com/ sites/ default/ files/ atoms/ files/ hud_ahar_ 2018_ 121718. pdf adresinden edinilmiştir.

Özdemir, U. (2010). Evsizlik ve evsizlere genel bir bakış. Toplum ve Sosyal Hizmet, 21(2), 7788.

Padgett, D. K., \& Struening, E. L. (1992). Victimization and traumatic injuries among the homeless: associations with alcohol, drug, and mental problems. American Journal of Orthopsychiatry, 62(4), 525-534.

Parker, R. D., \& Albrecht, H. A. (2012). Barriers to care and service needs among chronically homeless persons in a housing first program. Professional Case Management, 17(6), 278-284.

Raoult, D., Foucault, C., \& Brouqui, P. (2001). Infections in the homeless. The Lancet Infectious Diseases, 1(2), 77-84.

Reinking, D. P., Wolf, J. R., \& Kroon, H. (2001). High prevalence of mental disorders and addiction problems among the homeless in Utrecht. Nederlands Tijdschrift voor Geneeskunde, 145(24), 1161-1166.

Rifat, M. (2013). Açıklamalı göstergebilim sözlügü: kavramlar, yöntemler, kuramcılar, okullar. İstanbul: Türkiye İş Bankası Kültür Yayınları.

Rio Times (2017). Brezilya'daki Evsizler. 9 Temmuz 2019 tarihinde https:// riotimesonline. $\mathrm{com} /$ brazil- news/ rio- politics/ rios- homeless- population- increases-150- in- three- years/ adresinden edinilmiştir.

Rodell, D. E., Benda, B. B., \& Rodell, L. (2001). Effects of alcohol problems on depression among homeless veterans. Alcoholism Treatment Quarterly, 19(3), 65-81.

Sharing (2018). Dünya Genelinde Evsizlerin Oranı. 28 Haziran 2019 tarihinde https:// www. sharing. org/ information -centre /reports/ estimated-100- million- people- are- homelessworldwide adresinden edinilmiştir.

Shier, M. L., Jones, M. E., \& Graham, J. R. (2012). Employment difficulties experienced by employed homeless people: labor market factors that contribute to and maintain homelessness. Journal of Poverty, 16(1), 27-47.

Susser, E., Conover, S., \& Struening, E. L. (1990). Mental illness in the homeless: problems of epidemiologic method in surveys of the 1980s. Community Mental Health Journal, 26(5), 391414. 
The Guardian (2019). Avustralya'daki Evsizler. 9 Temmuz 2019 tarihinde https:// www. theguardian. com/ australia- news/ 2019/ may/30/ homelessness- becoming-concentrated -insydney- and- melbourne- study- finds adresinden edinilmiştir.

The Local (2019). Fransa'da Evsizler. 9 Temmuz 2019 tarihinde https:// www. thelocal. fr/ 20190319/ in- numbers- how- the- homeless- population- of- paris-is-growing adresinden edinilmiştir.

Türkcan, S., \& Türkcan, A. (1996). Psikiyatri ve evsizlik: bir gözden geçirme çalışması, Düşünen Adam, 9(4), 8-14.

Vostanis, P., Grattan, E., \& Cumella, S. (1998). Mental health problems of homeless children and families: longitudinal study. Bmj, 316(7135), 899-902.

Whitbeck, L. B., Hoyt, D. R., \& Bao, W. N. (2000). Depressive symptoms and co-occurring depressive symptoms, substance abuse, and conduct problems among runaway and homeless adolescents. Child Development, 71(3), 721-732.

Yale Global (2019). Evsiz Sayısında Yaşanan Artış. 26 Haziran 2019 tarihinde https:// yaleglobal. yale. edu/ content/ cities- grow- so -do- numbers- homeless adresinden edinilmiştir.

Yeter, A. (2018). Sivil toplum kuruluşlarının evsizlere yönelik hizmetlerinin değerlendirilmesi: İstanbul örneği. Yalova Sosyal Bilimler Dergisi, 8(17), 34-60.

Zima, B. T., Wells, K. B., \& Freeman, H. E. (1994). Emotional and behavioral problems and severe academic delays among sheltered homeless children in Los Angeles County. American Journal of Public Health, 84(2), 260-264. 